Article

\title{
Synthesis, In Vitro, In Vivo and In Silico Antidiabetic Bioassays of 4-Nitro(thio)phenoxyisobutyric Acids Acting as Unexpected PPAR $\gamma$ Modulators: An In Combo Study
}

\author{
Blanca Colin-Lozano ${ }^{1,2}$, Héctor Torres-Gomez ${ }^{1,3} \mathbb{D}^{\mathbb{D}}$, Sergio Hidalgo-Figueroa ${ }^{1,4}$, Fabiola Chávez-Silva ${ }^{1}$, \\ Samuel Estrada-Soto ${ }^{1}$ (D) Julio Cesar Almanza-Pérez ${ }^{5}$ (D) and Gabriel Navarrete-Vazquez ${ }^{1, *(D)}$
}

1 Facultad de Farmacia, Universidad Autónoma del Estado de Morelos, Cuernavaca, Morelos 62209, Mexico; clbi_ff@uaem.mx (B.C.-L.); Hector.Torres-Gomez@hki-jena.de (H.T.-G.); sergio.hidalgo@ipicyt.edu.mx (S.H.-F.); facasy@gmail.com (F.C.-S.); enoch@uaem.mx (S.E.-S.)

2 Facultad de Ciencias Químicas, Benemérita Universidad Autónoma de Puebla, Puebla 72000, Mexico

3 Leibniz Institute for Natural Products and Infection Biology, Hans Knöll Institute, 07745 Jena, Germany

4 CONACyT, Instituto Potosino de Investigación Científica y Tecnológica, San Luis Potosi 78216, Mexico

5 Laboratorio de Farmacología, Departamento de Ciencias de la Salud, Universidad Autónoma Metropolitana Iztapalapa, Mexico City 09340, Mexico; jcap@xanum.uam.mx

* Correspondence: gabriel_navarrete@uaem.mx; Tel.: +52-777-329-7089 (ext. 2322)

check for updates

Citation: Colin-Lozano, B.; Torres-Gomez, H.; Hidalgo-Figueroa, S.; Chávez-Silva, F.; Estrada-Soto, S.; Almanza-Pérez, J.C.;

Navarrete-Vazquez, G. Synthesis, In Vitro, In Vivo and In Silico Antidiabetic Bioassays of 4-Nitro(thio)phenoxyisobutyric Acids Acting as Unexpected PPAR $\gamma$ Modulators: An In Combo Study. Pharmaceuticals 2022, 15, 102. https://doi.org/10.3390/ph15010102 Academic Editors: Patrice Vanelle and Nicolas Primas

Received: 4 January 2022

Accepted: 13 January 2022

Published: 15 January 2022

Publisher's Note: MDPI stays neutral with regard to jurisdictional claims in published maps and institutional affiliations.

Copyright: (C) 2022 by the authors. Licensee MDPI, Basel, Switzerland. This article is an open access article distributed under the terms and conditions of the Creative Commons Attribution (CC BY) license (https:// creativecommons.org/licenses/by/ $4.0 /)$.

\begin{abstract}
Four isobutyric acids (two nitro and two acetamido derivatives) were prepared in two steps and characterized using spectral analysis. The mRNA concentrations of PPAR $\gamma$ and GLUT- 4 (two proteins documented as key diabetes targets) were increased by 3T3-L1 adipocytes treated with compounds 1-4, but an absence of in vitro expression of PPAR $\alpha$ was observed. Docking and molecular dynamics studies revealed the plausible interaction between the synthesized compounds and PPAR $\gamma$. In vivo studies established that compounds 1-4 have antihyperglycemic modes of action associated with insulin sensitization. Nitrocompound 2 was the most promising of the series, being orally active, and one of multiple modes of action could be selective PPAR $\gamma$ modulation due to its extra anchoring with Gln-286. In conclusion, we demonstrated that nitrocompound 2 showed strong in vitro and in vivo effects and can be considered as an experimental antidiabetic candidate.
\end{abstract}

Keywords: PPAR; drug design; diabetes; molecular dynamics

\section{Introduction}

Phenoxyisobutyric acid derivatives are a class of antihyperlipidemic agents, commonly known as fibrates, that act mainly as peroxisome proliferator-activated receptor (PPAR) modulators [1]. PPAR $\alpha$ and PPAR $\gamma$ are the protein targets of several endogenous fatty acids, which function as antidyslipidemic and insulin-sensitizing molecules [2]. In addition, PPAR $\gamma$ controls target genes involved in numerous biochemical pathways, such as the glucose transporter GLUT-4 [3]. Clofibrate, the first therapeutically useful fibrate, is an ethyl chlorophenoxyisobutyrate that acts as a prodrug, which is metabolized in vivo by esterases into its active metabolite, clofibric acid, that has shown strong hypolipidemic effect [4]. Recent studies showed that clofibrate and clofibric acid exerted a potent inhibitory activity against the enzyme $11 \beta$-hydroxysteroid dehydrogenase type 1 [5]. This enzyme catalyzes the conversion of inactive cortisone into the active hormone cortisol, a powerful glucocorticoid that acts as a contender of insulin action and stimulates gluconeogenesis in liver, leading to an increase in blood glucose levels and causing hyperglycemia [6]. Type 2 diabetes, a metabolic complication represented by hyperglycemia, is originated by insufficiency in production or action of insulin [7]. In our current research on antidiabetic compounds, we explain here the preparation of isobutyric acid derivatives 1-4 (Figure 1), their in vitro actions on PPAR $\alpha / \gamma$ and GLUT- 4 mRNA expression levels, the predictive biosimulations of their pharmacodynamics behavior and their in vivo effect in a murine 
model of diabetes. The collection of in vitro evaluations combined with in silico and in vivo estimations leads to the concept of in combo screening in antidiabetic drug discovery [5].<smiles>CCOC(=O)C(C)(C)Oc1ccc(Cl)cc1</smiles>

Clofibrate<smiles>CC(C)(Oc1ccc([N+](=O)[O-])cc1)C(=O)O</smiles><smiles>CCOC(=O)C(C)(C)Oc1ccc(NC(C)=O)cc1</smiles><smiles>CC(C)(Oc1ccc(Cl)cc1)C(=O)O</smiles>

Clofibric acid<smiles>CC(C)(Sc1ccc([N+](=O)[O-])cc1)C(=O)O</smiles><smiles>CC(=O)Nc1ccc(OC(C)(C)C(=O)O)cc1</smiles>

Figure 1. PPAR $\alpha$ modulators clofibrate and clofibric acid, containing phenoxyisobutyric acid pharmacophore, and the nitrocompounds (1-2) and acetamide compounds (3-4) designed in this work.

\section{Results and Discussion}

\subsection{Chemistry}

The preparation of compounds $\mathbf{1}-\mathbf{2}$ is described in Figure 2. Nucleophilic substitution of ethyl 2-bromo-2-methypropionate (7) with 4-nitrophenol (5) or 4-nitrothiophenol (6) in basic conditions and with acetonitrile as a solvent afforded the correspondent ethyl ester precursors as oil products. The ethyl esters formed were treated immediately with a mixture of THF/MeOH/ $\mathrm{H}_{2} \mathrm{O}$ (3:2:1) and hydrolyzed with five equivalents of $\mathrm{LiOH}$ to obtain compounds 1 and 2 in moderate yields (62.8 and 58.9\%, respectively). Compound 3 was produced in a similar way, employing 4-acetylaminophenol as a nucleophile in dimethylsulfoxide in basic media. A white solid was obtained in moderate yields (44\%). The subsequent selective ester hydrolysis of 3 with lithium hydroxide afforded 4 in $83.13 \%$ yield (Figure 2). All the reactions were monitored by thin layer chromatography (TLC), and the products were separated by filtration or extracted with $\mathrm{CH}_{2} \mathrm{Cl}_{2}$, affording the corresponding compounds 1-4, which were recovered with 44-83\% yields and purified by recrystallization with adequate solvent, as mentioned in the Section 3. Chemical structures were established by spectroscopic $\left({ }^{1} \mathrm{H},{ }^{13} \mathrm{C}\right.$ NMR) and spectrometric analysis. Purity was ascertained by microanalysis.

In the ${ }^{1} \mathrm{H}$ NMR spectra, the signals of the respective protons of the compounds were assigned, detecting the chemical shifts, multiplicities, and coupling constants $(J)$. All molecules exhibited a single signal ranging from $\delta_{\mathrm{H}} 1.46$ to $1.71 \mathrm{ppm}$, attributed to a geminal dimethyl group. All compounds displayed characteristic signals of 1,4-disubstitued benzene. The aromatic region of the ${ }^{1} \mathrm{H}$ NMR spectrum of compounds contained an $\mathrm{A}_{2} \mathrm{~B}_{2}$ pattern signal ranging from $\delta_{\mathrm{H}} 6.75$ to $7.65 \mathrm{ppm}\left(\mathrm{d}, J_{\text {ortho }}=8.7-9.6 \mathrm{~Hz}\right)$ and 7.45 to $8.17 \mathrm{ppm}$ $\left(\mathrm{d}, J_{\text {ortho }}=8.4-9.6 \mathrm{~Hz}\right)$, attributed to the equivalents $\mathrm{H}-2^{\prime}, \mathrm{H}-6^{\prime}$ and $\mathrm{H}-3^{\prime}, \mathrm{H}-5^{\prime}$ hydrogens, respectively. The displacement for carboxylic protons in 1, 2 and 4 was found between 9.83 and 10.6 ppm as a singlet. For compounds 3 and $\mathbf{4}$, a singlet signal for acetamide hydrogens was found ranging from $\delta_{\mathrm{H}} 2.0$ to $2.1 \mathrm{ppm}$. For the ${ }^{13} \mathrm{C}$ nuclear magnetic resonance spectra, constant signals were found for the benzene nucleus in all compounds, one signal ranging 
from $\delta_{C} 24.5$ to $25.7 \mathrm{ppm}$, attributed to a geminal dimethyl group. An additional signal ranging from $\delta_{C} 51.5$ to $79.8 \mathrm{ppm}$ was assigned to $\mathrm{C}-2$ of the ether bridge. In the aromatic region of the spectra, signals from 118.2-120.3 ppm and 120.2-136.1 ppm were assigned to $C-2^{\prime}, C-6^{\prime}$ and $C-3^{\prime}, C-5^{\prime}$, respectively. Other frequent signals were found in downfield shifts from $\delta_{C} 133.7-145.4 \mathrm{ppm}$, assigned to $C-4^{\prime}, 140.6-161.8 \mathrm{ppm}$ assigned to $C-1^{\prime}$, and 175.2-179.9 for the carboxylic acid group. For compounds 3 and 4, signals for the acetamide $\left(\mathrm{CH}_{3} \mathrm{CONH}-\right)$ were found ranging from $\delta_{\mathrm{C}} 23.8$ to $24.5 \mathrm{ppm}$ for the methyl group and 167.9 to $168.4 \mathrm{ppm}$ for the carbonyl group.<smiles>[Y6]O[Y10]#[Y6]</smiles><smiles>CCCOC(=O)C(C)(C)Br</smiles>

Figure 2. Synthesis of compounds 1-4. (a) $\mathrm{K}_{2} \mathrm{CO}_{3}, \mathrm{CH}_{3} \mathrm{CN}$, reflux; (b) $\mathrm{LiOH}$, $\mathrm{THF} / \mathrm{MeOH} / \mathrm{H}_{2} \mathrm{O}$; (c) $\mathrm{K}_{2} \mathrm{CO}_{3}, \mathrm{DMSO}, 80^{\circ} \mathrm{C}$; (d) $\mathrm{HCl}(10 \% v / v)$.

\subsection{In Vitro PPAR $\alpha / \gamma$ and GLUT-4 Expression}

Initially, the viability of 3T3-L1 fibroblasts were studied at increasing concentrations of 1,10 , and $100 \mu \mathrm{M}$ of compounds $\mathbf{1}-\mathbf{4}$ using the MTT assay, and no cytotoxicity was observed. For the in vitro mRNA expression of PPAR $\alpha$, PPAR $\gamma$, and GLUT-4, murine fibroblasts were differentiated to adipocytes to detect the action of molecules on the expression of genes. Cells were treated for $24 \mathrm{~h}$ with $10 \mu \mathrm{M}$ of compounds 1-4. Pioglitazone (PIO) and clofibrate (CLO) were used as positive controls [8,9].

The variation in the mRNA expression levels was estimated by qPCR. Figure 3 shows that compounds 1-4 unexpectedly augmented with statistical significance the mRNA expression of PPAR $\gamma$ (around two- to four-fold) and its downstream gene GLUT-4 (three-fold), as pioglitazone (PIO) did. PPAR $\gamma$ modulation decreases glycemia in diabetic individuals through an enhancement in insulin sensitization, and the rise in GLUT-4 concentrations in striated muscle is critical for glucose homeostasis. These unexpected results found in this study suggest that nitrocompounds 1, 2, and acetamide 4 stimulates GLUT-4 mRNA concentration greater than pioglitazone (Figure 3B). 

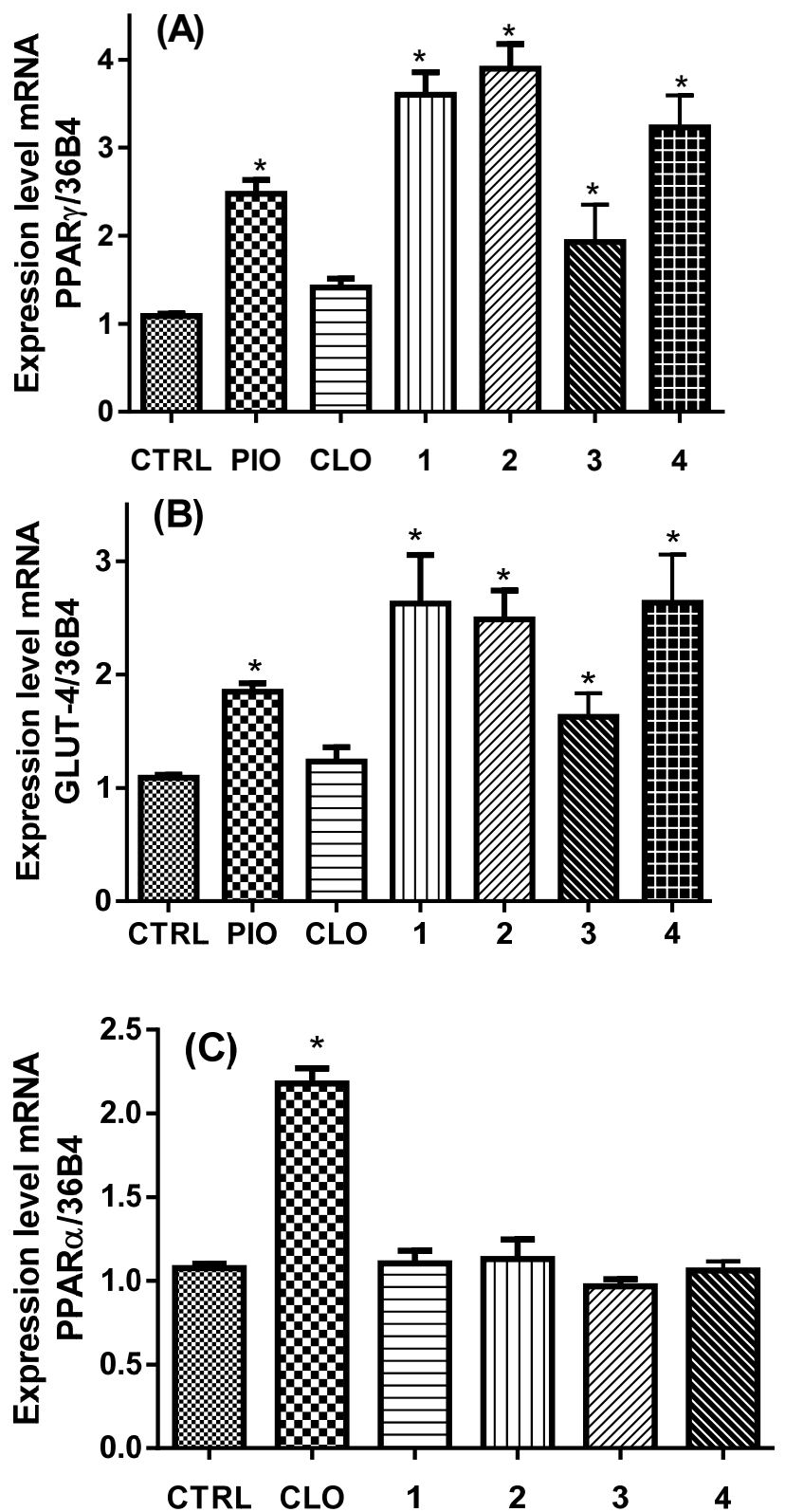

Figure 3. Changes on the expression of PPAR $\gamma(\mathbf{A})$, GLUT-4 (B), and PPAR $\alpha(\mathbf{C})$ genes induced by pioglitazone, clofibrate, and isobutyric acid derivatives $\mathbf{1 - 4}$. ${ }^{*}$ Statistically significant difference between control group and test samples were estimated using ANOVA with post hoc Dunnett's test ( $n=5$, mean \pm SEM, $p<0.001$ compared with CTRL group).

As expected, clofibrate (CLO) did not provoke a statistically significant rise in the mRNA expression level of PPAR $\gamma$ nor in GLUT-4 expression. Conversely, none of the compounds had activity over PPAR $\alpha$ expression, whereas clofibrate did. This implies that azasubstituents (nitro and acetamide), instead of the chlorine atom in the phenyl ring, provoke a selectivity of compounds over PPAR $\gamma$ instead PPAR $\alpha$ and are able to behave as selective PPAR modulators (SPPARM) [10].

\subsection{In Vivo Antidiabetic Action}

To confirm the possible hypoglycemic and/or antihyperglycemic action of compounds 1-4, we performed an in vivo acute experiment in streptozotocin (STZ)- and nicotinamide (NA)-induced diabetic mice, employing glibenclamide (Gli) as a hypoglycemic control in order to ensure that the damage to $\beta$-cells was partial and that the mice's pancreases still produced insulin and responded to a secretagogue drug. Additionally, we used pi- 
oglitazone as a positive control of an antihyperglycemic drug mediated by the PPAR $\gamma$ mechanism. Figure 4 shows the results of this experiment. Compounds 1, 2, and 4 administered at $100 \mathrm{mg} / \mathrm{kg}$ via intragastric route considerably decreased glycemia sixty minutes after oral administration and maintained their glycemic-lowering effect throughout the experiment in comparison with the vehicle (Tween 80,10\%). During the assay, glycaemia did not fall further than normal levels, as glibenclamide did, indicating that compounds 1-4 had an antihyperglycemic effect in agreement with insulin sensitization triggered by PPAR $\gamma$ activation [11], since the behavior of pioglitazone during the experiment was the same. It is important to note that compound 3 did not show a glycemic reduction effect until 5 and 7 hours post administration, its effect attributable to a possible prodrug of 4 which would need to be bioactivated by phase I hydrolysis within the murine organism.

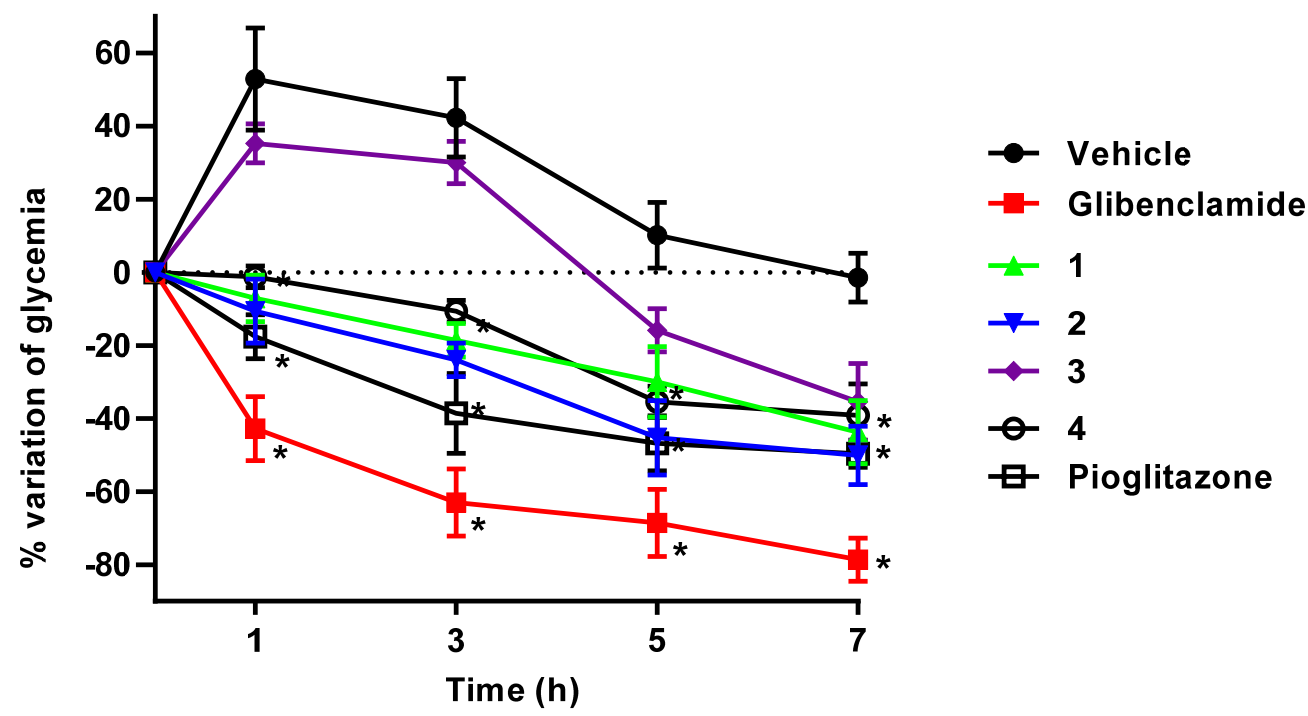

Figure 4. Effect of a intragastric single dose of $100 \mathrm{mg} / \mathrm{kg}$ of (thio)phenoxyisobutyric derivatives 1-4, glibenclamide, and pioglitazone on blood glucose levels in STZ/NA-induced diabetic mice. * Statistically significant difference between control group and test samples were estimated using ANOVA and a multiple comparison Dunnett's test $(n=6$, mean $\pm \mathrm{SEM}, p<0.05)$.

\subsection{Molecular Docking Calculations}

Once the in vitro activation of PPAR $\gamma$ and GLUT-4, as well as the in vivo antihyperglycemic effects, had been corroborated, compounds 1-4 were subjected to an in silico docking simulation. Docking calculations showed that molecules 1-4 enter into the ligandbinding pocket of PPAR $\gamma$ (PDB ID: 2F4B) and produce a net of hydrogen bonds with His-323 and several polar contacts with Cys-285, Tyr-327, Tyr-473, and His-449, key residues for the PPAR $\gamma$ activation (Figures 5 and 6). In the same way, (5-\{3-[(6-benzoyl-1-propyl-2naphthyl)oxy]propoxy\}-1H-indol-1-yl)acetic acid (EHA) was previously co-crystallized with PPAR $\gamma$ and shared the same contacts [12]. However, compound 3 had none of these types of relevant interactions, which correlates with the low activity shown both in vitro and in vivo studies. It is important to mention the participation of nitro group-containing compounds 1 and 2 in the network, generating polar contacts with His-449, His-323, and Ser-289. Clofibric acid was also docked in PPAR $\gamma$ for comparative purposes with the 4-azasubstituted-(thio)phenoxyisobutyric acids, showing less affinity than 1-4. Validation of docking yielded an RMSD value of $0.53 \AA^{2}$. PyMol and MOE [13] were employed for visualization. 

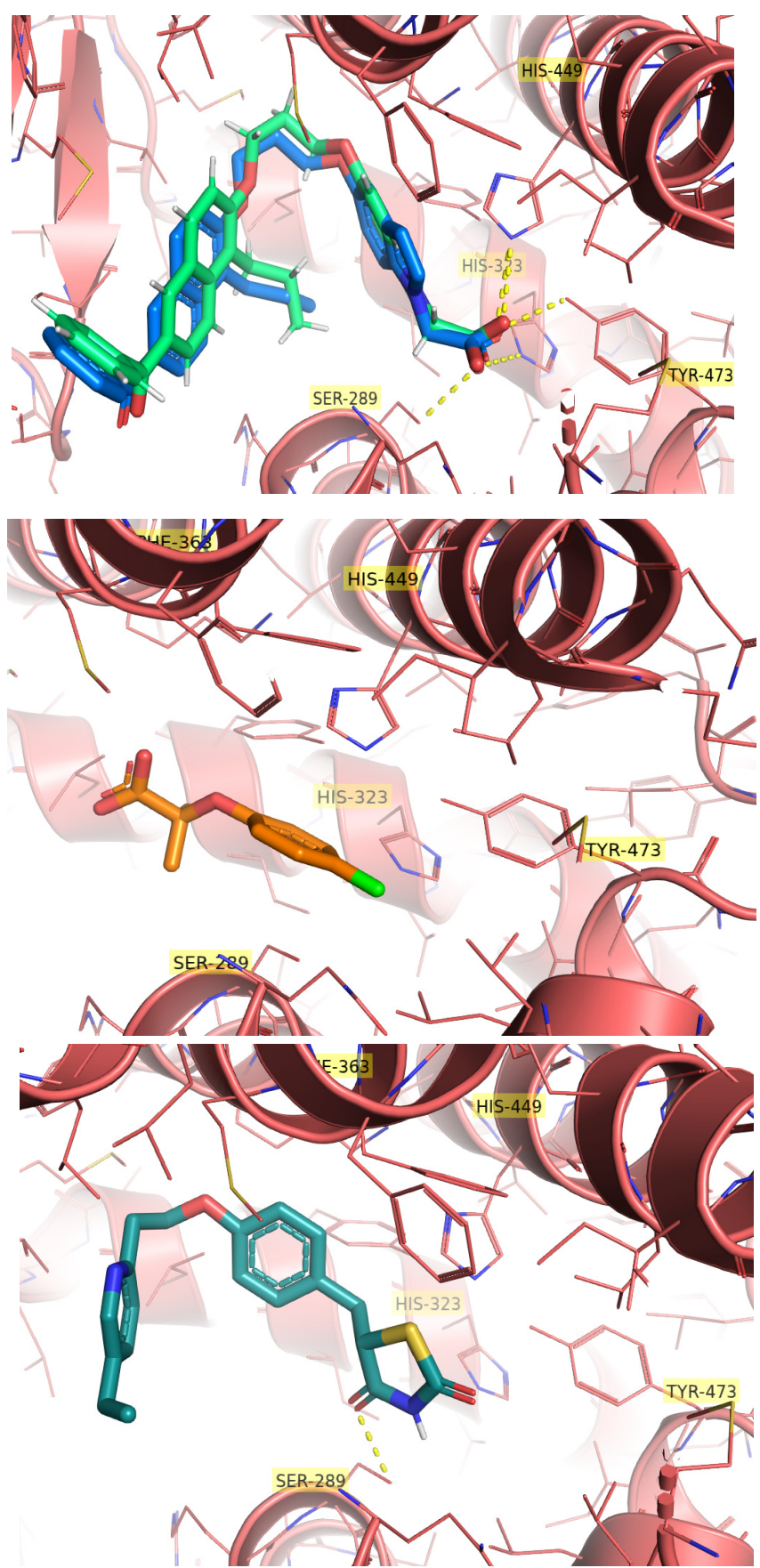

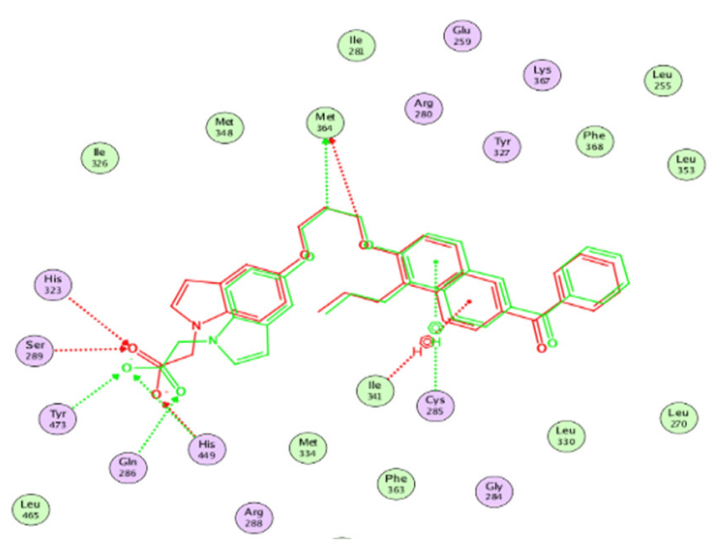

EHA, $\Delta \mathrm{G}=-8.2 \mathrm{Kcal} / \mathrm{mol}, \mathrm{RMSD}=0.53 \AA$

$\left(\begin{array}{ll}6 \text { IIn } \\ 285\end{array}\right.$

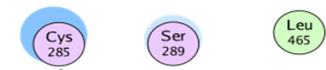

(Mec)

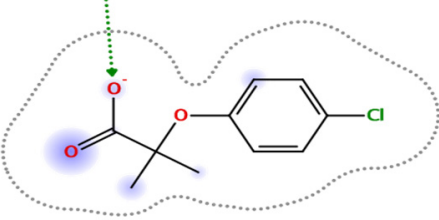

$\left(\begin{array}{l}116 \\ 326\end{array}\right)$

$\left(\begin{array}{lll}\text { Leu } \\ \text { 469 }\end{array}\right.$

(Tivi

Clofibric acid, $\Delta \mathrm{G}=-5.5 \mathrm{Kcal} / \mathrm{mol}$

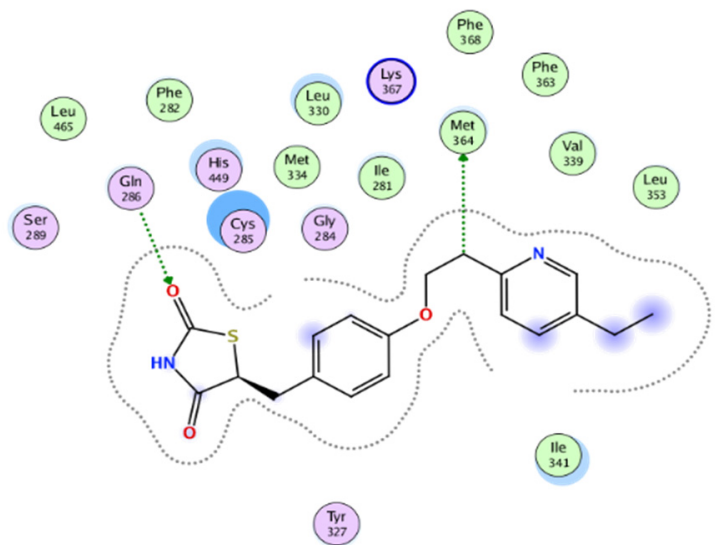

Pioglitazone, $\Delta \mathrm{G}=-8.5 \mathrm{Kcal} / \mathrm{mol}$

Figure 5. Three-dimensional pose of co-crystal structure reference of 2F4B (PPAR $\gamma$ )/EHA (carbon atoms colored blue, $\mathrm{X}$-ray; and green, redocked pose). Docked pose of clofibric acid (carbon atoms colored orange), pioglitazone (carbon atoms colored cyan), and its 2D diagram of interaction. (In the case of EHA, the 2D overlay complexes are displayed in green for the co-crystal X-ray representation and red for the re-docked pose.) 


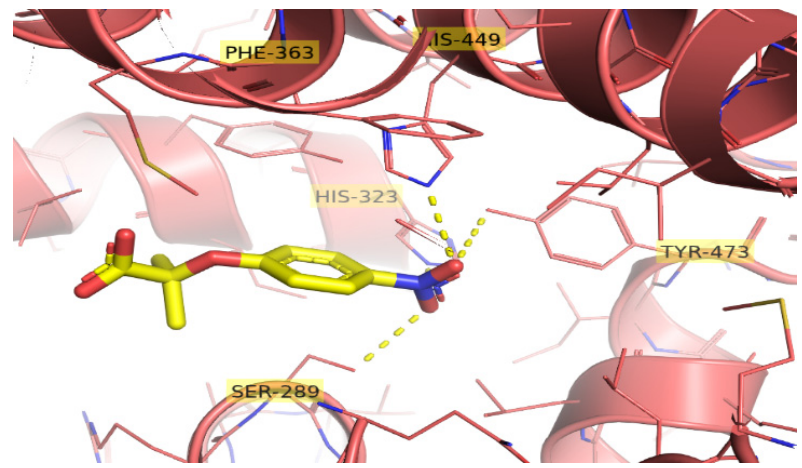<smiles>CCON(C)c1ccc(OC(C)(C)C)cc1</smiles>

(ser

(Leu 30 Arg

(11e

(Leu

1, $\Delta \mathrm{G}=-6.2 \mathrm{Kcal} / \mathrm{mol}$
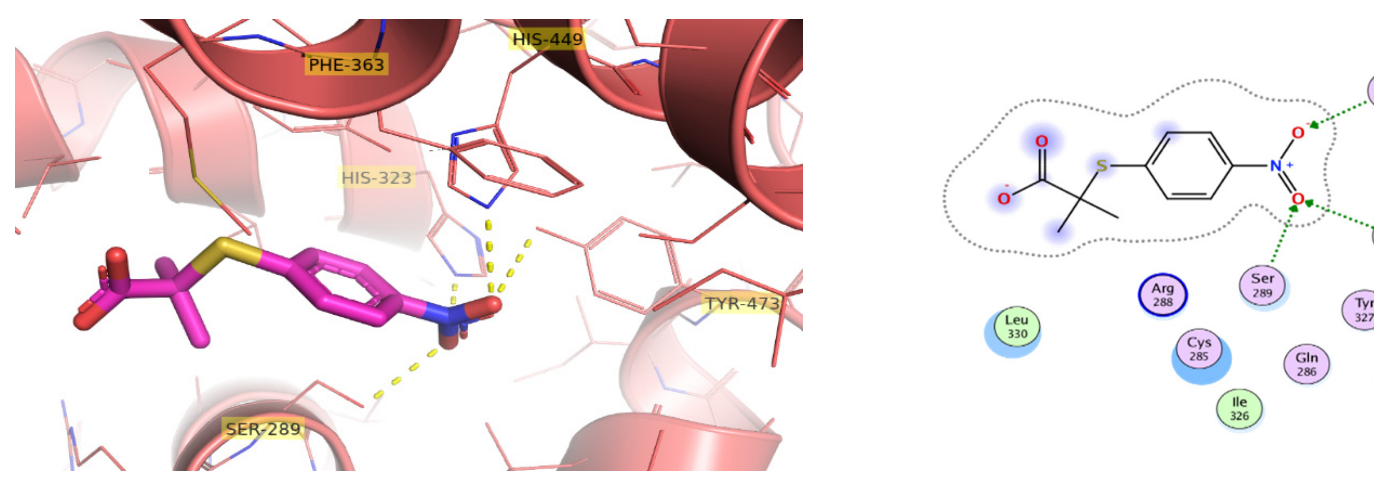

(Leu

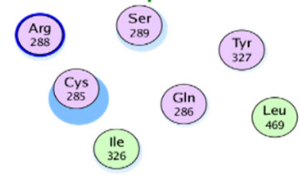

2, $\Delta \mathrm{G}=-6.2 \mathrm{Kcal} / \mathrm{mol}$

Met

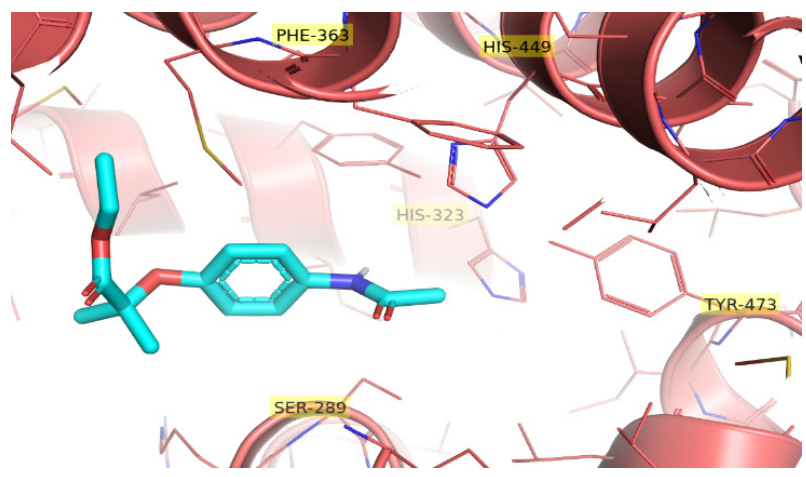

Leu

(112)

val

Met

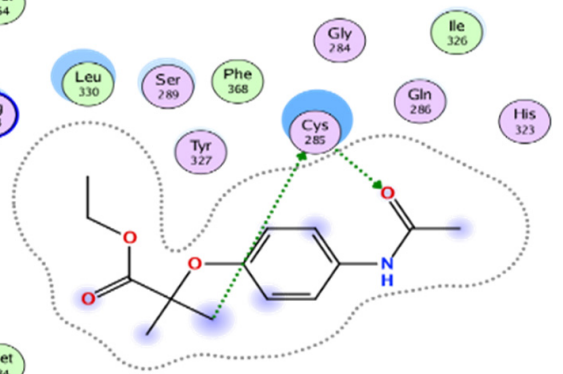

3, $\Delta \mathrm{G}=-6.0 \mathrm{Kcal} / \mathrm{mol}$

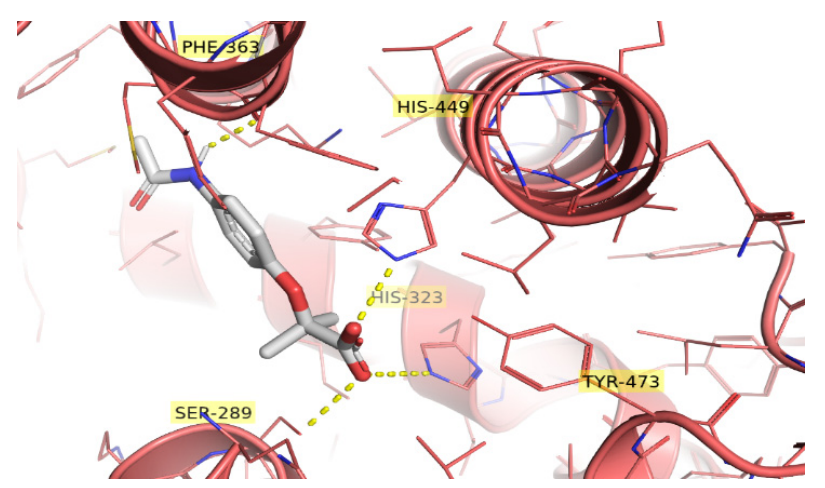

Leu

Met

(TVI)

(TrT

(455)

(6in<smiles>CCC(=O)N(C)c1ccc(OC(C)(C)C(=O)OC)cc1</smiles>

(Ser

(Cys

(Pre 282

4, $\Delta \mathrm{G}=-6.3 \mathrm{Kcal} / \mathrm{mol}$

Figure 6. Docked poses of 1 (carbon atoms colored yellow), 2 (carbon atoms colored magenta), 3 (carbon atoms colored cyan), and 4 (carbon atoms colored gray), and 2D diagram of interactions in the ligand-binding site of PPAR $\gamma$. 
Compound 3 (an ethyl ester) displayed a different conformation than its hydrolyzed product 4 (carboxylate ionized form). Although the benzene group was properly oriented to interact with the His-327 and Ser-289, the part of the ethyl ester was adapted to the side arm of the PPAR cavity (Figure 6). Molecular docking binding energies and calculated affinities $\left(K_{i}\right)$ on PPAR $\gamma$ agree with the behavior of compounds 1-4 and clofibrate in the in vitro and in vivo pharmacological screens (Table 1), suggesting that the antihyperglycemic effect displayed is mediated by insulin sensitization.

Table 1. Molecular docking binding energies, calculated affinities, molecular dynamics binding energies, and quantitative pharmacological actions for compounds 1-4, clofibric acid, and pioglitazone.

\begin{tabular}{|c|c|c|c|c|c|c|}
\hline Compound & $\begin{array}{c}\text { PPAR } \gamma \\
\Delta \mathrm{G} \\
\text { (kcal } / \mathrm{mol})\end{array}$ & $\begin{array}{c}K_{i} \\
(\mu \mathrm{M})\end{array}$ & $\begin{array}{c}\text { PPAR } \gamma / M D \\
\Delta \mathrm{G} \\
\text { (kcal/mol) }\end{array}$ & $\begin{array}{c}\text { PPAR } \gamma \\
\text { Expression Level } \\
\text { (Fold) }\end{array}$ & $\begin{array}{c}\text { GLUT-4 } \\
\text { Expression Level } \\
\text { (Fold) }\end{array}$ & $\begin{array}{c}\text { Maximal Percentage of } \\
\text { Glycemic-Lowering Effect } \\
(\%)\end{array}$ \\
\hline 1 & -6.2 & 5.39 & -7.3 & 3.60 & 2.62 & -43.5 \\
\hline 2 & -6.2 & 3.90 & -7.8 & 3.89 & 2.48 & -50.1 \\
\hline 3 & -6.0 & 7.54 & -7.2 & 1.92 & 1.62 & -35.3 \\
\hline 4 & -6.3 & 4.28 & -6.9 & 3.23 & 2.63 & -39.1 \\
\hline Clofibric acid & -5.5 & 13.13 & -6.8 & 1.41 & 1.02 & No reduction observed [5] \\
\hline Pioglitazone & -8.5 & 0.50 & -9.7 & 2.51 & 1.84 & -49.6 \\
\hline
\end{tabular}

\subsection{Molecular Dynamics Simulations}

The molecular dynamics simulation was used to analyze and understand the dynamic motion and the degree of stability of the complexes. The RMSD of the protein backbone and ligands is illustrated in Figure 7, where the complexes of nitrocompound 2 had initial stability after 2 ns. Interestingly, the two first complexes did not reveal RMSD values over $1.5 \AA$, which corroborates the rigorous conformation of the most active complexes. These complexes maintained a stable RMSD profile till the rest simulation. In Figure S1 (see Supplementary Materials), it was also observed that protein coupled to compound 4 and clofibric acid had similar RMSD profiles from 8 to 20 ns. Unlike the backbone of EHA and pioglitazone complexes, the RMSD profile indicates the degree of protein folding and unfolding importantly until reaching a semi-equilibrium at the end of the simulation. In contrast, in the values of the RMSD profile for the ligands, greater stability and less variation can be observed in terms of their structural conformation; however, the RMSD values for compounds 1, 2, and 4 oscillate between 1.5 after one nanosecond of simulation, which indicates that they easily find their conformation and stability in the active site, anchoring themselves to nearby amino acid residues previously predicted during the molecular docking study (see Supplementary Materials). This helps us to corroborate and to validate the molecular docking study. Finally, from Figure 7 we can observe that there is a conservation of anchoring with amino acids Lys-367, Tyr-327, and His-449 that retain most of the compounds. However, nitrocompound 2 showed an extra interaction with Gln-286. After 2 ns, compound 2 was anchored with its nitro group to Gln-286, His-466, and the carboxylate head with Lys-367 and Tyr-327 during $20 \mathrm{~ns}$ of simulation. Distinct to the rest of the compounds, nitroderivative 2 interacts with Gln-286, which undergoes a side chain reorientation in the complex, and it is evident that Gln-286 plays a key role in stabilizing helix 3 and 12 of PPAR $\gamma$ and has an important impact on receptor activity [14]. Taking into account that the partial modulators preferentially stabilized the $\beta$-sheet and $\mathrm{H} 3$ to a larger degree [15], nitrocompound 2 could belong to the partial modulators and it would show fewer adverse effects. Furthermore, the activity shown by this compound in the in vivo and in vitro models correlates with this greater stability found in the molecular dynamics studies and its extra anchoring with Gln-286. In addition, we decided to use another method to obtain the free binding energy of the molecular dynamics complex (PPAR $\gamma / M D)$. The PRODIGY-LIG web server [16] uses a refinement protocol in order to collect intermolecular energy and it is, therefore, suitable for every type of complex. To use the PRODIGY tools, we just needed to provide the 3D structure of our complex or complexes in PDB format 
and the ID. The PRODIGY-LIG web server predicts binding affinities with an accuracy of $1.89 \mathrm{kcal} / \mathrm{mol}$ (RMSE). The results are summarized in Table 1 . To obtain an outstanding compound, we analyzed and carried out the calculation to determine predictive binding energies through the PRODIGY-LIG web server [17]. The values obtained after submitting the complexes were approximate to free binding energies found in molecular docking, with slightly more negative values indicating a stronger binding along with molecular dynamics. The development of more balanced drugs interacting with PPARs, devoid of the side-effects shown by the currently marketed PPAR $\gamma$ full agonists, is considered the major challenge in drug design. For this reason, an alternative approach for the treatment of metabolic disorders is represented by the development of partial PPAR $\gamma$ agonists or selective PPAR $\gamma$ modulators (SPPARM), such as the compounds presented herein.

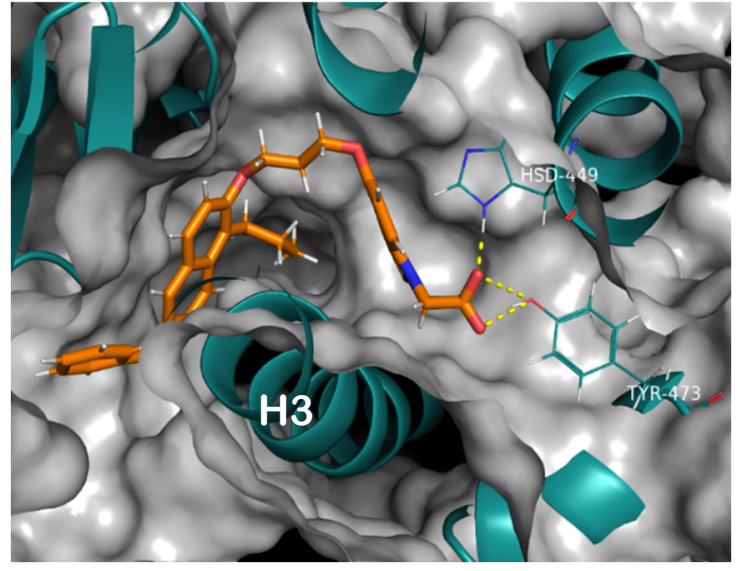

EHA

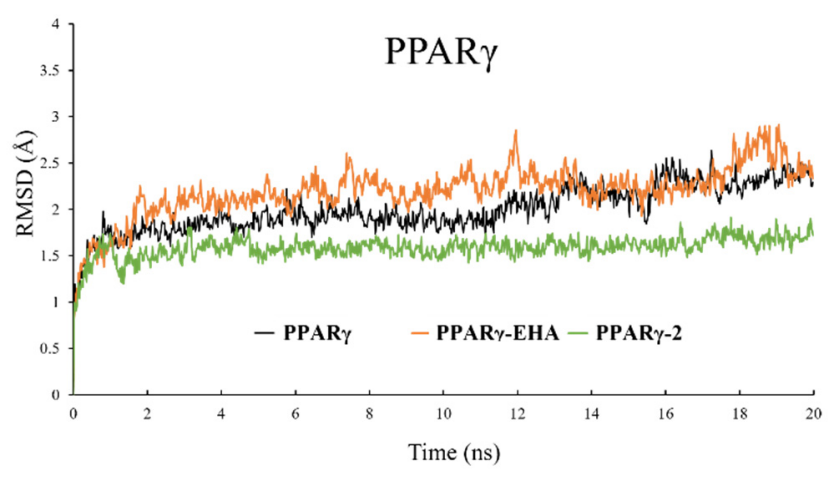

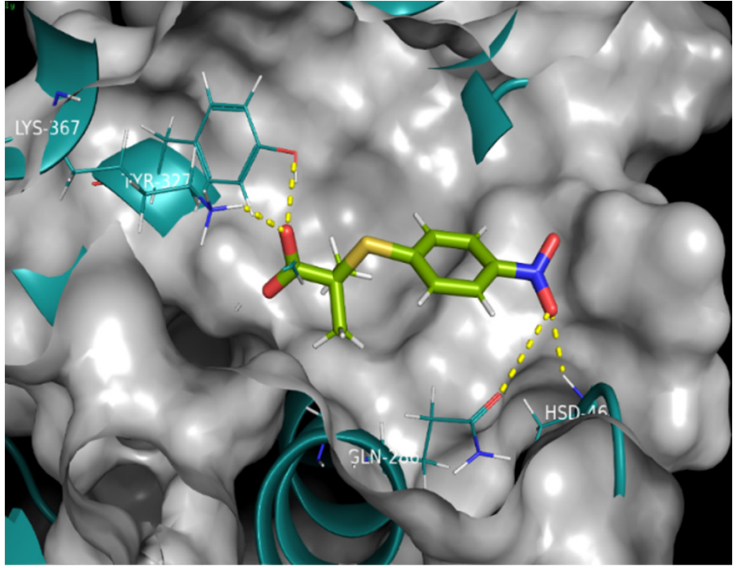

2

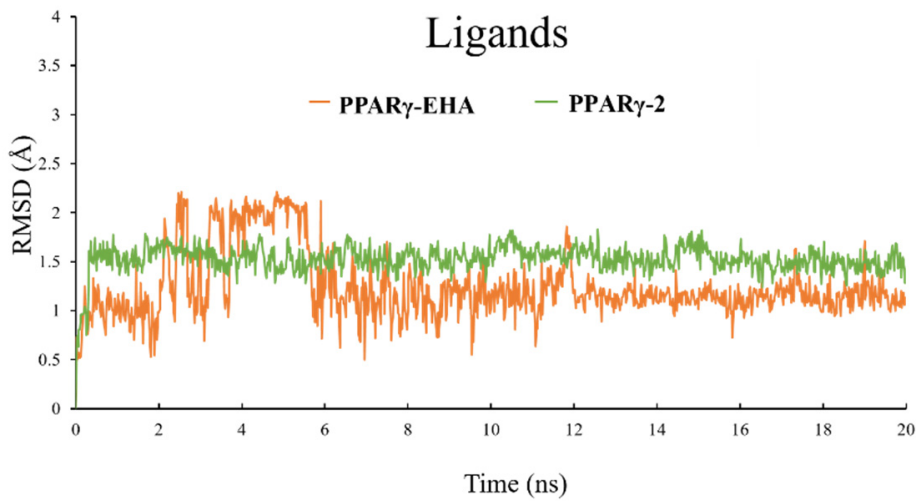

Figure 7. Hydrogen-bonding network of EHA (orange) and nitrocompound 2 (green) in the binding pocket of PPAR $\gamma$ (PDB code: 2F4B); RMSD of protein and ligands.

\subsection{In Silico Toxicology}

It is well known that drugs containing nitro groups can induce severe idiosyncratic toxicity and this is definitely the reason in many cases for their being avoided in drug design, considered as structural alerts [18]. However, the nitro group is also considered as both a pharmacophore and a selective toxicophore associated with organ-selective toxicity [19]. With the purpose of anticipating latent toxicity problems of compounds $\mathbf{1 - 4}$, a computational simulation of security profiles was performed. The toxicity parameters of 1-4, clofibrate, and pioglitazone were calculated employing ACD/ToxSuite, v. 2.95 (Table 2). 
Table 2. Predicted toxicity profiles calculated for compounds 1-4, clofibrate, and pioglitazone.

\begin{tabular}{|c|c|c|c|c|c|c|c|c|}
\hline \multirow{3}{*}{ Compound } & \multicolumn{4}{|c|}{$\mathrm{LD}_{50}(\mathrm{mg} / \mathrm{kg})$} & \multicolumn{4}{|c|}{$\begin{array}{l}\text { Probability of Inhibition/Blockage } \\
\left(\mathrm{IC}_{50} \text { or } K_{i}<10 \mu \mathrm{M}\right)\end{array}$} \\
\hline & \multicolumn{2}{|c|}{ Mouse } & \multicolumn{2}{|c|}{ Rat } & \multicolumn{3}{|c|}{ CYP450 Isoform } & \multirow[t]{2}{*}{ hERG } \\
\hline & i.p. & p.o. & i.p. & p.o. & 3A4 & 2D6 & 1A2 & \\
\hline 1 & 680 & 1500 & 820 & 1590 & 0.00 & 0.00 & 0.00 & 0.01 \\
\hline 2 & 670 & 790 & 520 & 1280 & 0.00 & 0.01 & 0.00 & 0.01 \\
\hline 3 & 810 & 1900 & 770 & 3000 & 0.02 & 0.01 & 0.19 & 0.05 \\
\hline 4 & 790 & 1400 & 970 & 2500 & 0.00 & 0.00 & 0.00 & 0.01 \\
\hline Clofibrate & 750 & 1300 & 1200 & 1800 & 0.03 & 0.04 & 0.31 & 0.12 \\
\hline Pioglitazone & 400 & 1400 & 400 & 1100 & 0.22 & 0.03 & 0.02 & 0.10 \\
\hline
\end{tabular}

The in silico calculation of inhibition for the three main isoforms of CYP450 for compounds 1-4 were comparable to clofibrate at relevant clinical concentrations $<10 \mu \mathrm{M}$, showing extremely low probabilities of drug-drug interactions and undesirable adverse effects. Compounds 1-4 showed very low prediction of hERG channel blockage at clinically relevant concentrations $\left(K_{i}<10 \mu \mathrm{M}\right)$, being considered as non-cardiotoxic molecules. In the calculation of acute toxicity, compounds $\mathbf{1 - 4}$ revealed similar $\mathrm{LD}_{50}$ values to clofibrate and pioglitazone by two different administration routes in two murine models. It is important to note that experimentally the viability of 3T3-L1 fibroblasts did not show any cytotoxicity provoked by compounds 1-4 assayed at $100 \mu \mathrm{M}$ concentration.

The term 'cliffs of toxicity' was coined in 2015 by our group [20] and taken up again in 2019 by other researchers [21] to define various nitrocompounds that have been reported as mutagenic and carcinogenic drugs (e.g., metronidazole, nimesulide, flutamide, nitazoxanide, among others) according to red flags included in most of the in silico tools that predict potentially toxic substructures and that nevertheless have a very low experimental toxicity [20]. In current work, compounds 1 and $\mathbf{2}$ could be considered toxicity cliffs due to the demonstrated lack of toxicity, in spite of the presence of a red flag in its structure.

On the other hand, in order to evaluate the pharmacokinetic profile of compounds 1-4, we used the platform ADMETLab 2.0 [22] to calculate the ADME profile (Table 3), starting with absorption parameters: GI absorption, blood-brain barrier permeability, and bioavailability.

Table 3. Pharmacokinetic predictive values calculated with ADMETLab 2.0 (https:/ / admetmesh. scbdd.com/ accessed on 5 March 2021) for compounds 1-4 and clofibrate.

\begin{tabular}{|c|c|c|c|c|c|c|}
\hline & \multirow{2}{*}{ Model } & \multicolumn{5}{|c|}{ Compounds } \\
\hline & & 1 & 2 & 3 & 4 & Clofibrate \\
\hline \multirow{3}{*}{ A } & Gastrointestinal Absorption & (+) High & (+) High & (+) High & (+) High & (+) High \\
\hline & Blood-Brain Barrier permeant & $(-)$ No & $(-)$ No & $(+)$ Yes & $(-)$ No & $(+)$ Yes \\
\hline & Bioavalability $(\mathrm{F})$ & $<20 \%$ & $>30 \%$ & $>30 \%$ & $>30 \%$ & $>30 \%$ \\
\hline \multirow{2}{*}{$\mathrm{D}$} & Plasma Protein Binding & $90.62 \%$ & $91.22 \%$ & $60.41 \%$ & $42.14 \%$ & $97.21 \%$ \\
\hline & Volume distribution & $0.23 \mathrm{~L} / \mathrm{kg}$ & $0.32 \mathrm{~L} / \mathrm{kg}$ & $0.95 \mathrm{~L} / \mathrm{kg}$ & $0.41 \mathrm{~L} / \mathrm{kg}$ & $1.403 \mathrm{~L} / \mathrm{kg}$ \\
\hline \multirow[b]{2}{*}{ M } & CYP3A4 substrate & (+) Yes & (+) Yes & $(++)$ Yes & $(+)$ Yes & $(++)$ Yes \\
\hline & CYP2D6 substrate & $(-)$ No & $(-)$ No & $(+)$ Yes & $(-)$ No & $(+)$ Yes \\
\hline \multirow{3}{*}{$\mathrm{E}$} & & 0.948 & 0.412 & 5.860 & 1.093 & 5.202 \\
\hline & & $\mathrm{mL} / \mathrm{min} / \mathrm{kg}$ & $\mathrm{mL} / \mathrm{min} / \mathrm{kg}$ & $\mathrm{mL} / \mathrm{min} / \mathrm{kg}$ & $\mathrm{mL} / \mathrm{min} / \mathrm{kg}$ & $\mathrm{mL} / \mathrm{min} / \mathrm{kg}$ \\
\hline & Half Life $\left(\mathrm{T}_{1 / 2}\right)$ & $>3 \mathrm{~h}$ & $>3 \mathrm{~h}$ & $>3 \mathrm{~h}$ & $>3 \mathrm{~h}$ & $>3 \mathrm{~h}$ \\
\hline
\end{tabular}

Compounds 1-4 present high values of absorption and only compound 3 and clofibrate are able to cross the BBB. The distribution parameters calculated were plasma protein binding and volume of distribution. Optimal plasma protein binding is less than $95 \%$ and all compounds met this parameter. However, compounds with high protein binding may have a low therapeutic index, such as clofibrate. Metabolic stability was also predicted, 
and compounds 1-4 are substrates of CYP450, which implies that this enzyme is the main metabolizing protein for most of the drugs that enter the body. To finish the ADME calculations, the excretion parameters were predicted, the compounds showing satisfactory values of clearance and long half-lives $(>3 \mathrm{~h})$ compared with clofibrate.

\section{Materials and Methods}

\subsection{Chemistry}

All reagents were purchased from Merck $^{\circledR}$ (Darmstadt, Germany) and were used without any extra purification. Using a Variant Oxford Instrument (Palo Alto, CA, USA, $600 \mathrm{MHz}$ and $150 \mathrm{MHz}$, respectively), ${ }^{1} \mathrm{H}$ and ${ }^{13} \mathrm{C}$ nuclear magnetic resonance spectra were obtained. Molecular masses were obtained with a JMS-700 spectrometer (JEOL, Tokyo, Japan) with an impact electronic method. Melting points were obtained using an EZ-Melt MPA120 automated apparatus from Stanford Research Systems (Sunnyvale, CA, USA).

\subsubsection{Procedure for the Synthesis of Compounds 1-4}

2-(4-Nitrophenoxy)isobutyric Acid (1)

To a mixture of 4-nitrophenol $(1.0 \mathrm{~g}, 4.44 \mathrm{mmol})$, potassium carbonate $(1.22 \mathrm{~g}, 8.88 \mathrm{mmol})$ in acetonitrile, ethyl 2-bromo-2-methylpropionate $(1.29 \mathrm{~g}, 1.04 \mathrm{~mL}, 6.66 \mathrm{mmol})$ was added dropwise. The mixture was stirred and heated under reflux for $8 \mathrm{~h}$, then poured onto cold water. The resulting oil was treated with a mixture of THF/MeOH/ $\mathrm{H}_{2} \mathrm{O}(3: 2: 1 v / v / v)$, $\mathrm{LiOH}$ (5 equiv.) was added, and the mixture was stirred at room temperature for $3 \mathrm{~h}$, then $10 \% \mathrm{HCl}$ solution was added and most of the organic solvents removed. The solid residue was extracted with dicloromethane $(3 \times 10 \mathrm{~mL})$ and the combined organic layers were dried with $\mathrm{Na}_{2} \mathrm{SO}_{4}$, filtered, and concentrated to give a yellow solid which was recrystallized from chloroform, m.p. 122.8-124.3 ${ }^{\circ} \mathrm{C}[23,24]$; yield 62.8\%. ${ }^{1} \mathrm{H} \mathrm{NMR}\left(200 \mathrm{MHz}, \mathrm{CDCl}_{3}\right)$ $\delta: 1.71\left(\mathrm{~s}, 6 \mathrm{H},\left(\mathrm{CH}_{3}\right)_{2}\right), 6.91\left(\mathrm{~d}, 2 \mathrm{H}, \mathrm{H}-2^{\prime}, \mathrm{H}-6^{\prime}, J=9.2 \mathrm{~Hz}\right), 8.16\left(\mathrm{~d}, 2 \mathrm{H}, \mathrm{H}-3^{\prime}, \mathrm{H}-5^{\prime}, J=9.6\right)$, $10.60\left(\mathrm{~s}, 1 \mathrm{H}, \mathrm{CO}_{2} \mathrm{H}\right)$ ppm. ${ }^{13} \mathrm{C} \mathrm{NMR}(50 \mathrm{MHz}, \mathrm{CDCl} 3) \delta: 25.5\left(\left(\mathrm{CH}_{3}\right)_{2}\right), 79.8(\mathrm{C}-2), 118.2$ $\left(\mathrm{C}-2^{\prime}, \mathrm{C}-6^{\prime}\right), 125.7\left(\mathrm{C}-3^{\prime}, \mathrm{C}-5^{\prime}\right), 142.3\left(\mathrm{C}-4^{\prime}\right), 160.6\left(\mathrm{C}-1^{\prime}\right), 179.1(\mathrm{COOH}) \mathrm{ppm} . \mathrm{MS} / \mathrm{EI}: \mathrm{m} / z(\%$ rel. int.). $225\left(\mathrm{M}^{+}, 1 \%\right), 180(\mathrm{M}-45,100 \%)$. Anal. calcd. for $\mathrm{C}_{10} \mathrm{H}_{11} \mathrm{NO}_{5}: \mathrm{C}, 53.33 ; \mathrm{H}, 4.92 ; \mathrm{N}$, 6.22. Found: $\mathrm{C}, 53.41 ; \mathrm{H}, 4.83 ; \mathrm{N}, 6.28$.

\section{2-(4-Nitrophenylsulfanyl)isobutyric Acid (2)}

To a mixture of 4-nitrothiophenol $(1.0 \mathrm{~g}, 6.40 \mathrm{mmol})$, potassium carbonate $(1.94 \mathrm{~g}$, $14.1 \mathrm{mmol})$ in acetonitrile, ethyl 2-bromoisobutyrate $(1.37 \mathrm{~g}, 7.04 \mathrm{mmol})$ was added dropwise. The mixture was stirred and heated under reflux for $6 \mathrm{~h}$. After that, the mixture was poured onto cold water. The resulting oil was treated with a mixture of THF $/ \mathrm{MeOH} / \mathrm{H}_{2} \mathrm{O}$ (3:2:1, $v / v / v)$, and $\mathrm{LiOH}$ was added (5 equiv.). The mixture was stirred at room temperature for $3 \mathrm{~h}$. Then, $\mathrm{HCl}$ solution $(10 \% v / v)$ was added, and most of the organic solvents removed. The solid residue was extracted with dichloromethane $(3 \times 10 \mathrm{~mL})$ and the combined organic layers were dried with $\mathrm{Na}_{2} \mathrm{SO}_{4}$, filtered, and concentrated to give a yellow solid which was recrystallized from chloroform, m.p. 121.9-123.7 ${ }^{\circ} \mathrm{C}[25,26]$; yield $58.9 \% .{ }^{1} \mathrm{H}$ NMR $\left(400 \mathrm{MHz}, \mathrm{CDCl}_{3}\right) \delta: 1.56\left(\mathrm{~s}, 6 \mathrm{H},\left(\mathrm{CH}_{3}\right)_{2}\right), 7.65\left(\mathrm{dd}, 2 \mathrm{H}, \mathrm{H}-2^{\prime}, \mathrm{H}-6^{\prime}, J=2.6\right.$, $J=9.6 \mathrm{~Hz}), 8.17\left(\mathrm{dd}, 2 \mathrm{H}, \mathrm{H}-3^{\prime}, \mathrm{H}-5^{\prime}, J=2.6, J=9.6 \mathrm{~Hz}\right), 10.60\left(\mathrm{~s}, 1 \mathrm{H}, \mathrm{CO}_{2} \mathrm{H}\right) \mathrm{ppm} .{ }^{13} \mathrm{C}$ NMR

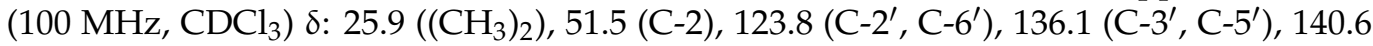
$\left(\mathrm{C}-1^{\prime}\right), 145.4\left(\mathrm{C}-4^{\prime}\right), 179.9(\mathrm{COOH}) \mathrm{ppm} . \mathrm{MS} / \mathrm{EI}: \mathrm{m} / z$ (\% rel. int.). 241 (M+1\%), 196 (M-45, $100 \%$ ). Anal. calcd. for $\mathrm{C}_{10} \mathrm{H}_{11} \mathrm{NO}_{4} \mathrm{~S}: \mathrm{C}, 49.78 ; \mathrm{H}, 4.60 ; \mathrm{N}, 5.81 ; \mathrm{S}, 13.29$. Found: $\mathrm{C}, 49.69 ; \mathrm{H}$, $4.60 ; \mathrm{N}, 5.87 ; \mathrm{S}, 13.36$.

\section{Ethyl 2-[4-(acetylamino)phenoxy]isobutyrate (3)}

In the minimum amount of dimethylsulfoxide, 4-Acetylaminophenol ( $1 \mathrm{~g}, 6.6 \mathrm{mmol})$ and potassium carbonate $(2 \mathrm{~g}, 14 \mathrm{mmol})$ were dissolved and heated at $40{ }^{\circ} \mathrm{C}$. After $20 \mathrm{~min}$, the ethyl 2-bromo-2-methylpropionate $(1.45 \mathrm{~mL}, 9.9 \mathrm{mmol})$ was added dropwise and the reaction mixture was heated to reflux $\left(80^{\circ} \mathrm{C}\right)$ and monitored by TLC. After the reaction completion $(15 \mathrm{~h})$, the mixture was filtered and the solid residue was recrystallized from 
acetone. White crystals, m.p. $90.1-92.3{ }^{\circ} \mathrm{C}$ [27]; yield 44.0\%. ${ }^{1} \mathrm{H}$ NMR $(200 \mathrm{MHz}$; DMSO-d 6 ; $\left.\mathrm{Me}_{4} \mathrm{Si}\right) \delta: 1.17\left(3 \mathrm{H}, \mathrm{t}, \mathrm{CH}_{3}\right), 1.47\left(6 \mathrm{H}, \mathrm{s},\left(\mathrm{CH}_{3}\right)_{2}\right), 2.00\left(3 \mathrm{H}, \mathrm{s}, \mathrm{CH}_{3} \mathrm{CO}\right), 4.15\left(2 \mathrm{H}, \mathrm{q}, \mathrm{CH}_{2}\right)$, $6.75\left(2 \mathrm{H}, \mathrm{d}, \mathrm{H}-2^{\prime}, \mathrm{H}-6^{\prime}, J=8.7 \mathrm{~Hz}\right), 7.45\left(2 \mathrm{H}, \mathrm{d}, \mathrm{H}-3^{\prime}, \mathrm{H}-5^{\prime}, J=8.7 \mathrm{~Hz}\right), 9.83(1 \mathrm{H}, \mathrm{bs}, \mathrm{N}-\mathrm{H})$ ppm. ${ }^{13} \mathrm{C} \mathrm{NMR}\left(50 \mathrm{MHz}, \mathrm{DMSO}-\mathrm{d}_{6}\right) \delta: 14.6\left(\mathrm{CH}_{3}\right), 24.5\left(\mathrm{CH}_{3} \mathrm{CO}\right), 25.7\left(\left(\mathrm{CH}_{3}\right)_{2}\right), 61.6(\mathrm{C}-2)$, $79.5\left(\mathrm{CH}_{2}-\mathrm{O}\right), 120.3\left(\mathrm{C}-2^{\prime}, \mathrm{C}^{\prime} 6^{\prime}\right), 120.7\left(\mathrm{C}-3^{\prime}, \mathrm{C}-5^{\prime}\right), 134.7\left(\mathrm{C}-4^{\prime}\right), 150.9\left(\mathrm{C}-1^{\prime}\right), 168.4(\mathrm{NHC}=\mathrm{O})$, $173.7(\mathrm{O}-\mathrm{C}=\mathrm{O})$ ppm. EI-MS: $m / z$ (rel. int.) $265\left(\mathrm{M}^{+}, 25 \%\right), 192(25 \%), 151(50 \%), 109(100 \%)$. Anal. calcd. for $\mathrm{C}_{14} \mathrm{H}_{19} \mathrm{NO}_{4}$ : C, 63.38; $\mathrm{H}, 7.22 ; \mathrm{N}, 5.28$. Found: $\mathrm{C}, 63.38 ; \mathrm{H}, 7.07 ; \mathrm{N}, 5.53$.

\section{2-(4-Acetamidophenoxy)isobutyric Acid (4)}

Compound $3(0.5 \mathrm{~g}, 1.88 \mathrm{mmol})$ was treated with a mixture of tetrahydrofuran $/ \mathrm{H}_{2} \mathrm{O}$ $(5: 1, v / v)$ and $\mathrm{LiOH}$ was added (3 equiv.). The mixture was stirred at room temperature for $3 \mathrm{~h}$. Then, $\mathrm{HCl}$ solution $(10 \% \mathrm{v} / \mathrm{v})$ was added and most of the organic solvents removed. The solid residue was extracted with $\mathrm{CH}_{2} \mathrm{Cl}_{2}(3 \times 10 \mathrm{~mL})$, dried with $\mathrm{Na}_{2} \mathrm{SO}_{4}$, filtered, and concentrated to give a white solid which was recrystallized from methanol, m.p. 164.4-166.3 ${ }^{\circ} \mathrm{C}$ [28]; yield 83.13\%. ${ }^{1} \mathrm{H}$ NMR (200 MHz; DMSO- $\left.d_{6} ; \mathrm{Me}_{4} \mathrm{Si}\right) \delta 1.46(6 \mathrm{H}, \mathrm{s}$, $\left.\left(\mathrm{CH}_{3}\right)_{2}\right), 2.10\left(3 \mathrm{H}, \mathrm{s}, \mathrm{CH}_{3} \mathrm{CO}\right), 6.78\left(2 \mathrm{H}, \mathrm{d}, \mathrm{H}-2^{\prime}, \mathrm{H}-6^{\prime}, J=8.7 \mathrm{~Hz}\right), 7.44\left(2 \mathrm{H}, \mathrm{d}, \mathrm{H}-3^{\prime}, \mathrm{H}_{-}\right.$ $\left.5^{\prime}, J=8.7 \mathrm{~Hz}\right), 9.83(2 \mathrm{H}, \mathrm{bs}, \mathrm{N}-\mathrm{H}, \mathrm{COOH}) \mathrm{ppm} .{ }^{13} \mathrm{C}$ NMR $\left(50 \mathrm{MHz}, \mathrm{DMSO}-d_{6}\right) \delta: 23.8$ $\left(\mathrm{CH}_{3} \mathrm{CO}\right), 25.1\left(\left(\mathrm{CH}_{3}\right)_{2}\right), 78.7(\mathrm{C}-2), 119.5\left(\mathrm{C}-2^{\prime}, \mathrm{C}^{\prime} 6^{\prime}\right), 120.2\left(\mathrm{C}-3^{\prime}, \mathrm{C}-5^{\prime}\right), 133.9\left(\mathrm{C}-4^{\prime}\right), 161.8$ $\left(\mathrm{C}-1^{\prime}\right), 167.9(\mathrm{NHC}=\mathrm{O}), 175.2(\mathrm{COOH}) \mathrm{ppm}$. EI-MS: $\mathrm{m} / z$ (rel. int.) $237\left(\mathrm{M}^{+}, 5 \%\right), 192(\mathrm{M}-45$, $100 \%$ ). Anal. calcd. for $\mathrm{C}_{12} \mathrm{H}_{15} \mathrm{NO}_{4}$ : C, 60.75; H, 6.37; N, 5.90. Found: C, 60.8; H, 6.39; N, 5.85 .

\subsection{Biological Assays \\ GLUT-4 and PPAR Quantification}

Confluent cultures of 3T3-L1 fibroblasts were differentiated to the adipocytes, employing $0.25 \mu \mathrm{M}$ of dexamethasone acetate, $0.5 \mathrm{mM}$ of 3-isobutyl-1-methylxanthine, and $0.8 \mu \mathrm{M}$ bovine insulin. After 10 days, the cells gained the matured adipocyte phenotype and were preserved for $24 \mathrm{~h}$ to observe the effects of cumulative concentrations of 1-4 on GLUT-4 and PPAR $\gamma$ mRNA expression levels. Total mRNA was isolated from adipocytes, and $2 \mu \mathrm{g}$ was transcribed by RT-PCR. The cDNA was amplified using SYBR Green Master Mix containing $0.5 \mathrm{mM}$ of customized primers for GLUT-4 (GenBank accession: NM009204.2), PPAR $\gamma$ (GenBank accession: NM011146.1), and PPAR $\alpha$ (GenBank accession: NM011144). PCR was used for individually sampling and calculating the threshold cycles $(\mathrm{Ct})$ and the $\Delta \mathrm{Ct}$ values. The quantity of mRNA for each gene was normalized according to the amount of mRNA encoding ribosomal protein 36B4 (Gene Bank NM007475.2). The $\Delta$ Ct values were calculated in every sample for each gene of interest. Oscillations in the relative expression levels of independently specific genes $(\Delta \Delta \mathrm{Ct})$ were measured and graphed $[8,9]$.

\subsection{In Vivo Antidiabetic Assay}

\subsubsection{Animals}

ICR male mice weighing $25 \pm 5 \mathrm{~g}$ were housed in animal cages with periods of $12 \mathrm{~h}$ light and $12 \mathrm{~h}$ dark. Mice were maintained at $25^{\circ} \mathrm{C}$ environment, with water and food access ad libitum. All mouse experiments were conducted according to protocols that were approved by the Mexican government NOM-065-ZOO-1999 and NOM-033-ZOO-2014 and ratified by the Institutional Ethics Committee of the Universidad Autónoma Metropolitana (dictum 1857), based on US National Institutes of Health Publication \#85-23, revised 1985.

\subsubsection{Acute Antidiabetic Assay}

Induction of diabetes was executed agreeing to earlier works [5,8]. Mice were fasted for $8 \mathrm{~h}$. Nicotinamide was dissolved in saline water and administered i.p. at a dose of $20 \mathrm{mg} / \mathrm{kg}$. Fifteen minutes later, streptozotocin was administered i.p. in a citrate buffer $0.05 \mathrm{M}, \mathrm{pH}=4.5$, at a dose of $100 \mathrm{mg} / \mathrm{kg}$. Mice that developed blood glucose levels over $180 \mathrm{mg} / \mathrm{dL}$ were selected for the in vivo assay. The animals were fasted for $8 \mathrm{~h}$ and the groups' $(n=6)$ doses were administered orally, $100 \mathrm{mg} / \mathrm{kg}$ of the different 
compounds, including one vehicle group (10\% Tween 80$)$ and two positive control groups (glibenclamide, $20 \mathrm{mg} / \mathrm{kg}$; pioglitazone, $30 \mathrm{mg} / \mathrm{kg}$ ). Blood glucose concentrations were measured at $0,1,3,5$, and $7 \mathrm{~h}$ post administration, employing a blood sugar monitoring device (Accu-Check Performa).

\subsection{In Silico Docking Calculations}

In silico calculations were performed with Autodock Vina [29]. The crystal structure of PPAR $\gamma$ (pdb id: 2F4B), complexed with EHA at $2.07 \AA$ resolution, was obtained from the Protein Data Bank (http:/ / www.rcsb.org/pdb accessed on 5 January 2021). All water molecules were deleted, non-polar hydrogen atoms were merged, and the hydrogens atoms and Gasteiger charges were added in MGLTools 1.5.4 [30]. The 3D structures were built, minimized, and ionized in MOE, using the MMFf94 forcefield [13]. The grid was centered at the crystallographic coordinates of EHA (center_x $=8.693$; center_y $=-6.961$; and center_z $=39.672$ ) and the grid dimensions were $40 \times 40 \times 40$ points with $0.375 \AA$ of spacing. One hundred independent Genetic Algorithm runs from AutoDock were processed using the built-in clustering analysis with a $2.0 \AA$ cutoff. In concordance with a validation procedure to reproduce by docking, the same pose of co-crystallized ligand in the crystal structure (RMSD $=0.53 \AA$ ) was used, with a score of $-8.2 \mathrm{Kcal} / \mathrm{mol}$. After the molecular docking, we analyzed the best calculated binding poses, and the graphical representations were performed by Surface Maps and Ligand Interaction from MOE [13] and PyMol software.

\section{Docking Validation}

The docking protocols were validated by EHA (co-crystal ligand) into the PPAR $\gamma$ ligand-binding site of 2F4B. The root mean square deviation (RMSD) between the co-crystal ligand and the redocked molecule was $0.53 \AA$, specifying that the parameters for docking calculations are replicating conformation and orientation in the X-ray crystal of PPAR $\gamma$.

\subsection{Molecular Dynamics Simulations}

The obtained complexes of compound 1-4, clofibric acid, pioglitazone, and EHA with PPAR $\gamma$ protein (PDB code: $2 \mathrm{~F} 4 \mathrm{~B}$ ) were used to perform the molecular dynamics simulations. The objective of this work was to evaluate the stability and behavior of ligand-receptor complexes previously tested in in vitro and in vivo studies, with the earlier published protocol [31].

\subsection{Statistical Analysis}

To analyze the differences in the percent variation of glycemia and the in vitro PPAR $\gamma$ and GLUT-4 quantification, we employed ANOVA, complemented with a Dunnett's multiple test. All values were expressed as the mean \pm S.E.M. $p<0.05$, using GraphPad Prism 5.0 for the analysis.

\section{Conclusions}

In summary, four 4-azasubstituted (thio)phenoxyisobutyric acids have been synthesized and they significantly increased mRNA expression of PPAR $\gamma$ and GLUT-4, to a greater extent than clofibrate and pioglitazone. All of them showed selective activation of $\operatorname{PPAR} \gamma$ over PPAR $\alpha$. Their main difference with clofibrate is the absence of the chlorine atom in position 4 of the benzene ring and the incorporation of azasubstituents, such as nitro (compounds 1, 2) and acetamide groups (compounds 3, 4). Compounds 1, 2, and 4 also showed oral antihyperglycemic effects in the diabetic rat model, consistent with insulin sensitization and with their behaving as selective PPAR $\gamma$ modulators (SPPARM), such as pioglitazone. Finally, based on the findings of molecular dynamics simulations, nitrocompound $\mathbf{2}$ proved outstanding for its stability in the ligand-receptor complex and could belong to the partial modulators due to its extra anchoring formed with its nitro group and Gln-286. 
Supplementary Materials: The following are available online at https:/ / www.mdpi.com/article/ 10.3390/ph15010102/s1, Figure S1: Hydrogen-bonding network of EHA (orange), Pioglitazone (pink), Clofibric acid (yellow) and compounds 1-4 (red, green, deep blue and cyan, respectively) in the binding pocket of PPAR $\gamma$ (PDB code: 2F4B); RMSD of Protein and Ligands.

Author Contributions: B.C.-L. and H.T.-G. performed the synthesis of compounds, acquired the antidiabetic in vivo data, and analyzed the chemical and biological results. S.H.-F. performed and analyzed the molecular docking and dynamics of protein complexes. J.C.A.-P. performed the PPAR's assay and drafted some parts of the manuscript. S.E.-S. and F.C.-S. carried out and explained the antidiabetic assays and drafted some parts of the manuscript. G.N.-V. developed the concept, designed the compounds, acquired funding, and prepared and wrote the manuscript. All authors have read and agreed to the published version of the manuscript.

Funding: This research and part of the APC were funded by the Consejo Nacional de Ciencia y Tecnología (CONACyT), grant no. 253814 (Ciencia Básica 2015), grant no. 252881 (PEI 2018), and grant no. 377882/2020 (FORDECYT-PRONACES).

Institutional Review Board Statement: The study was conducted according to the guidelines of the Declaration of Helsinki and approved by the Institutional Review Board of Universidad Autónoma Metropolitana (protocol code: 1857; date of approval: 31 January 2019).

Informed Consent Statement: Not applicable.

Data Availability Statement: Data is contained within the article and Supplementary Files.

Acknowledgments: We appreciate the support of "Facultad de Farmacia, Universidad Autónoma del Estado de Morelos" for providing some research supplies for this study. We are indebted to Jesus Vladimir Hernández Rosado for his technical assistance with the PPAR assay. This article is dedicated to Alicia Hernandez-Campos, from Facultad de Quimica, UNAM, for her enthusiasm in the preparation and teaching of Mexican students in the experimental area of organic and medicinal chemistry.

Conflicts of Interest: The authors declare that there are no competing interests.

Sample Availability: Samples of the compounds are available from the authors.

\section{References}

1. Giampietro, L.; Ammazzalorso, A.; Amoroso, R.; De Filippis, B. Development of fibrates as important scaffolds in medicinal chemistry. ChemMedChem 2019, 14, 1051-1066. [CrossRef]

2. Maltarollo, V.G.; Kronenberger, T.; Windshugel, B.; Wrenger, C.; Trossini, G.H.G.; Honorio, K.M. Advances and challenges in drug design of PPAR Ligands. Curr. Drug Targets 2018, 19, 144-154. [CrossRef]

3. Pujimulyani, D.; Yulianto, W.A.; Setyowati, A.; Arumwardana, S.; Sari Widya Kusuma, H.; Adhani Sholihah, I.; Rizal, R.; Widowati, W.; Maruf, A. Hypoglycemic activity of Curcuma mangga Val. extract via modulation of GLUT4 and PPAR-gamma mRNA expression in 3T3-L1 adipocytes. J. Exp. Pharmacol. 2020, 8, 363-369. [CrossRef]

4. Thorp, J.M.; Waring, W.S. Modification of metabolism and distribution of lipids by ethyl chlorophenoxyisobutyrate. Nature 1962, 194, 948-949. [CrossRef] [PubMed]

5. Navarrete-Vázquez, G.; Alaniz-Palacios, A.; Hidalgo-Figueroa, S.; González-Acevedo, C.; Ávila-Villarreal, G.; Estrada-Soto, S.; Webster, S.P.; Medina-Franco, J.; López-Vallejo, F.; Guerrero-Álvarez, J.; et al. Discovery, synthesis and in combo studies of a tetrazole analogue of clofibric acid as a potent hypoglycemic agent. Bioorg. Med. Chem. Lett. 2013, 23, 3244-3247. [CrossRef] [PubMed]

6. Webster, S.P.; Ward, P.; Binnie, M.; Craigie, E.; McConnell, K.M.M.; Sooy, K.; Vinter, A.; Seckl, J.R.; Walker, B.R. Discovery and biological evaluation of adamantyl amide 11beta-HSD1 inhibitors. Bioorg. Med. Chem. Lett. 2007, 17, 2838-2843. [CrossRef] [PubMed]

7. Álvarez-Almazán, S.; Filisola-Villaseñor, J.G.; Alemán-González-Duhart, D.; Tamay-Cach, F.; Mendieta-Wejebe, J.E. Current molecular aspects in the development and treatment of diabetes. J. Physiol. Biochem. 2020, 76, 13-35. [CrossRef] [PubMed]

8. Gutierréz-Hernández, A.; Galván-Ciprés, Y.; Domínguez-Mendoza, E.A.; Aguirre-Vidal, Y.; Estrada-Soto, S.; Almanza-Pérez, J.C.; Navarrete-Vázquez, G. Design, synthesis, antihyperglycemic studies, and docking simulations of benzimidazolethiazolidinedione hybrids. J. Chem. 2019, 2019, 1650145. [CrossRef]

9. Giacoman-Martínez, A.; Alarcón-Aguilar, F.J.; Zamilpa, A.; Hidalgo-Figueroa, S.; Navarrete-Vázquez, G.; García-Macedo, R.; Román-Ramos, R.; Almanza-Pérez, J.C. Triterpenoids from Hibiscus sabdariffa L. with PPAR $\delta / \gamma$ dual agonist action: In Vivo, in vitro and in silico studies. Planta Med. 2019, 85, 412-423. [CrossRef] 
10. Giampietro, L.; Laghezza, A.; Cerchia, C.; Florio, R.; Recinella, L.; Capone, F.; Ammazzalorso, A.; Bruno, I.; De Filippis, B.; Fantacuzzi, M.; et al. Novel phenyldiazenyl fibrate analogues as PPAR $\alpha / \gamma / \delta$ pan-agonists for the amelioration of metabolic syndrome. ACS Med. Chem. Lett. 2019, 10, 545-551. [CrossRef] [PubMed]

11. Sugii, S.; Olson, P.; Sears, D.D.; Saberi, M.; Atkins, A.R.; Barish, G.D.; Hong, S.H.; Castro, G.L.; Yin, Y.Q.; Nelson, M.C.; et al. PPAR $\gamma$ activation in adipocytes is sufficient for systemic insulin sensitization. Proc. Natl. Acad. Sci. USA 2009, 106, 22504-22509. [CrossRef]

12. Mahindroo, N.; Wang, C.C.; Liao, C.C.; Huang, C.F.; Lu, I.L.; Lien, T.W.; Peng, Y.H.; Huang, W.J.; Lin, Y.T.; Hsu, M.C.; et al. Indol-1-yl acetic acids as peroxisome proliferator-activated receptor agonists: Design, synthesis, structural biology, and molecular docking studies. J. Med. Chem. 2006, 49, 1212-1226. [CrossRef] [PubMed]

13. Molecular Operating Environment (MOE). Chemical Computing group ULC; 1010 Sherbooke St. West, Suite \#910: Montreal, QC, Canada, 2021; Available online: http:/ / www.chemcomp.com (accessed on 5 January 2021).

14. Pochetti, G.; Godio, C.; Mitro, N.; Caruso, D.; Galmozzi, A.; Scurati, S.; Loiodice, F.; Fracchiolla, G.; Tortorella, P.; Laghezza, A.; et al. Insights into the mechanism of partial agonism: Crystal structures of the peroxisome proliferator-activated receptor gamma ligand-binding domain in the complex with two enantiomeric ligands. J. Biol. Chem. 2007, 282, 17314-17324. [CrossRef]

15. Bruning, J.B.; Chalmers, M.J.; Prasad, S.; Busby, S.A.; Kamenecka, T.M.; He, Y.; Nettles, K.W.; Griffin, P.R. Partial agonists activate PPARgamma using a helix 12 independent mechanism. Structure 2007, 15, 1258-1271. [CrossRef] [PubMed]

16. Vangone, A.; Schaarschmidt, J.; Koukos, P.; Geng, C.; Citro, N.; Trellet, M.E.; Xue, L.; Bonvin, A.M. Large-scale prediction of binding affinity in protein-small ligand complexes: The PRODIGY-LIG web server. Bioinformatics 2019, 35, 1585-1587. [CrossRef]

17. Kurkcuoglu, Z.; Koukos, P.I.; Citro, N.; Trellet, M.E.; Rodrigues, J.P.G.L.M.; Moreira, I.S.; Roel-Touris, J.; Melquiond, A.S.; Geng, C.; Schaarschmidt, J.; et al. Performance of HADDOCK and a simple contact-based protein-ligand binding affinity predictor in the D3R Grand Challenge 2. J. Comp. Aid. Mol. Des. 2018, 32, 175-185. [CrossRef]

18. Nepali, K.; Lee, H.Y.; Liou, J.P. Nitro-Group-Containing Drugs. J. Med. Chem. 2019, 62, 2851-2893. [CrossRef] [PubMed]

19. Li, J.J. Medicinal Chemistry for Practitioners, 1st ed.; Wiley: New York, NY, USA, 2020.

20. Medina-Franco, J.L.; Navarrete-Vázquez, G.; Méndez-Lucio, O. Activity and property landscape modeling is at the interface of chemoinformatics and medicinal chemistry. Future Med. Chem. 2015, 7, 1197-1211. [CrossRef]

21. Alberga, D.; Trisciuzzi, D.; Mansouri, K.; Mangiatordi, G.F.; Nicolotti, O. Prediction of Acute Oral Systemic Toxicity Using a Multifingerprint Similarity Approach. Toxicol. Sci. 2019, 167, 484-495. [CrossRef] [PubMed]

22. Xiong, G.; Wu, Z.; Yi, J.; Fu, L.; Yang, Z.; Hsieh, C.; Yin, M.; Zeng, X.; Wu, C.; Lu, A.; et al. ADMETlab 2.0: An integrated online platform for accurate and comprehensive predictions of ADMET properties. Nucleic Acids Res. 2021, 49, W5-W14. [CrossRef]

23. Wang, B.; Tang, C.; Han, Y.; Guo, R.; Qian, H.; Huang, W. Synthesis and preliminary antihyperlipidaemic activities evaluation of andrographolide derivatives. Med. Chem. 2012, 8, 293-298. [CrossRef]

24. Lalezari, I.; Rahbar, S.; Lalezari, P.; Fermi, G.; Perutz, M.F. LR16, a compound with potent effects on the oxygen affinity of hemoglobin, on blood cholesterol, and on low density lipoprotein. Proc. Natl. Acad. Sci. USA 1988, 85, 6117-6121. [CrossRef]

25. Navarrete-Vázquez, G.; Villalobos-Molina, R.; Estrada-Soto, S.; Ortiz-Andrade, R.; Tlahuext, H. 2-Methyl-2-(4-nitrophenylsulfanyl) propanoic acid. Acta Crystallogr. Sect. E Struct. Rep. Online 2008, 64, o91. [CrossRef] [PubMed]

26. Andreani, F.; Andrisano, R.; Andreani, A. New alpha-substituted arylthioacetic derivatives forming analogues of clofibrate. Farmaco Sci. 1975, 30, 847-858. [PubMed]

27. Navarrete-Vázquez, G.; Torres-Gómez, H.; Guerrero-Álvarez, J.; Tlahuext, H. Synthesis and crystal structure of ethyl 2-[4(acetylamino)phenoxy]-2-methylpropanoate, a potential anti-inflammatory and Antidyslipidemic Hybrid. J. Chem. Crystallogr. 2011, 41, 732-736. [CrossRef]

28. Navarrete-Vázquez, G.; Colín-Lozano, B.; Tlahuext, H.; Tapia-Benavides, A.R. 2-(4-Acetamidophenoxy)-2-methylpropanoic acid. Acta Crystallogr. Sect. E Struct. Rep. Online 2013, 9, o443. [CrossRef] [PubMed]

29. Trott, O.; Olson, A.J. AutoDock Vina: Improving the speed and accuracy of docking with a new scoring function, efficient optimization, and multithreading. J. Comput. Chem. 2010, 31, 455-461. [CrossRef] [PubMed]

30. Jiang, X.; Kumar, K.; Hu, X.; Wallqvist, A.; Reifman, J. DOVIS 2.0: An efficient and easy to use parallel virtual screening tool based on AutoDock 4.0. Chem. Cent. J. 2008, 2, 18. [CrossRef]

31. Hidalgo-Figueroa, S.; Rodríguez-Luévano, A.; Almanza-Pérez, J.C.; Giacoman-Martínez, A.; Ortiz-Andrade, R.; León-Rivera, I.; Navarrete-Vázquez, G. Synthesis, molecular docking, dynamic simulation and pharmacological characterization of potent multifunctional agent (dual GPR40-PPAR $\gamma$ agonist) for the treatment of experimental type 2 diabetes. Eur J Pharmacol. 2021, 907, 174244. [CrossRef] 